\title{
THE RELATIONSHIP BETWEEN HIGH-TECHNOLOGY EXPORTS, PATENT AND ECONOMIC GROWTH IN TURKEY (1990-2015)
}

DOI: 10.17261/Pressacademia.2019.1124

JBEF-V.8-ISS.3-2019(4)-p.173-180

\section{Deniz Dilara Dereli}

Istanbul Kultur University, Department of Economics, Basin Ekspres Campus, Kucukcekmece, Istanbul, Turkey d.dereli@iku.edu.tr, ORCID: 0000-0002-9697-4517

Date Received: June 1, 2019

Date Accepted: September 18, 2019

To cite this document

Dereli, D.D., (2019). The relationship between high-technology exports, patent and economic growth in Turkey (1990-2015). Journal of Business, Economics and Finance (JBEF), V.8(3), p.173-180

Permemant link to this document: http://doi.org/10.17261/Pressacademia.2019.1124

Copyright: Published by PressAcademia and limited licenced re-use rights only.

\section{ABSTRACT}

Purpose- Today technology ise one of the main driving force of economic growth. Indicators as high-technology exports and patent show the progress of technological development of economies. In this study evaluation of the relationship between high-technology exports, patent and economic growth in Turkey was aimed.

Methodology- The relationship between high-technology exports, patent and economic growth in Turkey have been investigated for $1990-2015$ period. The stationary of variables have been tested by Augmented Dickey-Fuller (ADF) test, the causality relationship between variables have been investigated by Vector Autoregressive (VAR)Granger Causality test. For long term relationship Johansen Cointegration test and Vector Error Correction (VEC) Granger Causality test have been conducted respectively.

Findings- Study results showed a causality relationship from both high-technology exports and patent to economic growth. A long term relationship has been identified by Johansen Cointegration test and one way causality relationship has been also found from both high-technology exports and patent to economic growth in long term.

Conclusion- The study results showed that both high-technology exports and patent accelerate economic growth in short and long term. In Turkey policies should be establish in order to support the production and exportation of high-technology products and to increase patent applications.

Keywords: High-technology exports, patent, economic growth, causality, co-integration.

JEL Codes: E60, 011, 047

\section{INTRODUCTION}

In economics, two approaches come to the forefront in explaining how economic growth occurs in a country. The Neo-Classic Growth Model proposed by Solow (1956), Swan (1956), assumes technology as an external component and the Endogenous Growth Models developed by Arrow (1962), Romer (1986, 1990), Lucas (1988), Grossman and Helpman (1991a, 1991b) and Aghion ve Howit (1992) assume the technology endogenous. Although both growth models argue that technological development is the source of economic growth, endogenous growth models explain how technological development occurs in countries and how it promotes the economic growth (Özçelik et al., 2018).

Today, it is emphasized that the growth phenomenon is related to the level of technology that countries have. According to an economist, technology is a measurement technique that is wedged between input and output and a tool which increases the welfare and living standards of nations. In engineering it is defined as series of methods for production. In general, technology is also defined as a source of knowledge that is used to improve the efficiency of production, marketing of the existing goods and 
services and to produce new goods and services. With its dynamic structure, technology is a criterion used in the classification of countries and developed countries determine their industrialization and economy policies according to technology. It is generally accepted in the world that there is a significant positive relationship between the countries' high technology production and economic growth and development. On the basis of this view, it can be clearly stated that economic growth policies that are evaluated independently from technological developments will be deficient (Algan et al., 2017).

As advanced technology production means producing both high value-added and high yielding products at the same time, especially developed countries are the leading countries in the world in terms of high-tech product exports. In this context, the production and export of high-technology products is an extremely important source of financing for the growth and development of the countries that have adopted the export-oriented growth strategy by increasing their export revenues. In this respect, it is possible to say that exports are one of the most important economic activities that cause the growth of the economy and development of the countries by providing foreign currency inflow to the country (Konak, 2018).

Owning high-technology elements provides many important advantages to countries, the most important of which is the economic growth. Especially in developed countries, infrastructure investments for technological development have emerged as one of the most important factors of economic growth over time and have constituted the basis of technological developments. Technological developments and innovations contribute to increase the production potential and productivity directly. The positive developments in technology enable more effective use of factors of production by increasing efficiency in the production process, which, in return, accelerates economic growth and development and consequently, improves the life quality and life standards of individuals (Konak, 2018). And by patenting new ideas and inventions as a result of R \& D activities, countries gain competitiveness in international markets and export high technology goods based on new ideas and inventions (Özçelik et al., 2018).

In Turkey, Science \& Technology policies were introduced at the end of the 1970s and has been given priority in the 7th Five-Year Development Plan. In 1980, priority was given to incentive measures to increase export revenues but adverse effect was experienced on technological development because the expected income did not turn into R\&D investments. In 2001, with a new legislation on creation of technology development regions, academicians and researchers were more easily involved and engaged in the processes of technology production. Through initiative of KOSGEB, two technology development centers as the centers of innovation were founded at METU and ITU. By 2008, the number of the similar centers were increased to 30. However, only few of them were successful. Another important development in the recent history of Turkey is the establishment of the Scientific and Technological Research Council of Turkey (TÜBITAK) in 1963. It is the leading agency for management, funding and conduct of research in Turkey. It was established in 1963 with a mission to advance science and technology, conduct research and support Turkish researchers. Additionally, in 1983, the "Supreme Council for Science and Technology" and "Council of Science, Technology and Innovation Policies" have been established. TUBITAK and Supreme Council for Science and Technology aim to create an "affluent society" which is competent in science and technology; uses technology consciously and capable of developing new technologies; and possess the skill of converting technological developments into social and economic benefits (TÜBiTAK, 2004).

Since technological innovation is one of the most important factors determining the competitiveness of a country on a global basis, it directly affects both the foreign trade volume and growth rates of the country. The countries that have achieved competitive advantage in science and technology are generally ranked in the category of industrialized country while the countries producing labor intensive goods and services are ranked in the status of developing countries. At the first stage of development, developing countries specialize in labour intense industries since they have abundant and cheap labour force. However, they can not compete with developed countries in time (Alper, 2017).

Export-driven growth strategy, which emerged as an alternative to import substitution policies in the late 1970s, is expressed as a development strategy aimed at increasing production capacity through foreign trade. Since then, export-based growth strategies have been adopted and implemented by many countries. However, significant part of the countries adopting this strategy couldn't achieved the their targets because of the differences between the export patterns of the countries and the change in the locomotive sectors in exports. In the end, some of these countries achieved their goals in a short period of time, while others were far behind the race. This situation is explained directly in relation to the value added in exports. The added value in exports is closely related to the quality of the products subject to export. The production of advanced technology also means the production of high value-added products. The fact that these goods are subject to exports provides a significant source of financing growth and development by increasing export revenues especially for countries following export-based growth strategies (Yıldız, 2017). 
In this study, firtsly selected empirical studies conducted in the literature have been shared. After the methodology has been explained the analyses have been carried out. The causality relationship between high-technology exports, patent and economic growth have been examined by VAR (Vector Autoregressive) Granger Causality test and long term relationship has been investigated by Johansen Cointegration test and Vector Error Correction (VEC) Granger causality test. The aim of this study is to determine the relationship between high-technology exports, patent and economic growth and evaluate the policies needed related with the findings.

\section{LITERATURE REVIEW}

Different studies exist which examines the relationship between high-technology export, patent and economic growth in different countires/country groups for different terms. Selected studies and their results have been shared which conducted various methods:

Konak (2018) examined the impact of high technology on economic growth in Turkey for 1992-2016 period. According to the study results the share of export products with high technology in Turkey's total exports, the tapering period in 1999-2001, except to be as occurs at lower level than $2 \%, 1999-2001$ sub-period, the rates in question but can rise up to $4 \%$, Turkey's exports mainly "low", "low-medium" and "medium-high" technology has been found to be based on.

Kabaklarlı et al (2018) investigated the long term relationship between high-technology exports and economic growth in selected OECD countries for 1989-2015 period. A long-term relationship between high-technology exports and economic growth is found. While patent applications and foreign direct investment play a decisive role on high-technology exports, growth rate and investment effect high-technology exports negatively.

Özkan and Yılmaz (2017) examined the relationships between the share of R\&D expenditures in GDP, the share of high-technology exports in total exports and GDP in Turkey and $12 \mathrm{EU}$ members by panel data analysis for 1996-2015 period. As a result for R\&D expenditures have positive effect on high-technology exports and GDP.

Algan et al. (2017), investigated the relationship between the share of R \& D expenditure in GDP, the number of patent applications and GDP per capita by Granger causality test for 1996-2015 period and found one-way causality from high-tech product exports and R \& D spending to GDP per capita, and one-way causality relationship from GDP per capita to patent application numbers in short term. In long-term $R$ \& D expenditures and patent applications have resulted in a positive GDP per capita, while high-technology exports negatively affected.

In his study Yıldız (2017) exmained the effect of the high- technology export on the economic growth for BRICS countries and Turkey by Panel Data Analysis for 2005-2014 period. As a result of the study significant and positive effect of high- technology export on economic growth was found in both Panel Fix Effect and Panel Random Effect models.

Aali Bujari and Venegas Martínez (2016) analyzed the impact of technological innovation on economic growth for 12 representative countries in Latin America for 1996-2008 period with dynamic panel data model and estimated with Generalized Method of Moments (GMM) system. As a result of study it is found that technological innovation have a positive impact on economic growth in the region, suggesting that Latin American countries might achieve economic growth in a context of incentives for technological innovation and investment in research, patents and exports of high-tech products are relevant to raise the total factor productivity and increase per capita GDP in most Latin American countries.

Ustabaş ve Ersin (2016) investigated the relationship between high-technology exports and economic growth by conducting causality and cointegration tests in South Africa and Turkey for 1989-2014 period. They found that high-technology exports effect economic growth positively in Turkey in short term. In South Africa positive effect of he high-technology exports on economic growth occurs in both short and long term.

Telatar, Değer and Doğanay (2016) conducted time series analysis for Turkey by using the data between 1996:1-2015:3 period an investigated the the effect of technology intensity product export on economic growth By Engle-Granger(1987) co-integration test and Granger causality test the relationship between variables were examined. A significant and positive effect of low and medium technology intensive products on economic growth was determined. Additionally unidirectional causality relationship from exports of medium and high technology intensive products to economic growth was found. 
Işı (2014) analyzed the importance of patent rights for the economic growth in Turkey in order to establish economy policies. Patent expenses and economic growth are analyzed for1990:1-2010:4 period by Granger cointegration models and a unidirectional relationship between patent expenses and economic growth is found.

Song and Nan (2014) examined the relationship between economic growth and technologic innovations by Vector Autoregressive (VAR) model and a long term relationship between variables is found.

Weng et al. (2012), with the help of VAR analysis, tried to analyze the relationship between foreign direct investments, patent application, technology-based trade share and economic growth for Shanghai between 1991 and 2009. As a result of study, a positive correlation between economic growth and other technological indicators is reached.

Kılavuz and Topçu Altay (2012) examined the correlation between growth in export and economic growth in 22 developing countires for 1998-2006 period by establishing 2 models. In the first model including variables such as high and low-tech manufacturing industry exports, investment and population, they found that only high-tech manufacturing industry export and investment, have a positive and significant effect on growth. In the second model the effect of high and low-techology manufacturing industry imports on growth is investigated and it is found that only high-technology manufacturing industry export, investment and low-technology manufacturing industry import have a positive and significant effect on growth.

Zhang et al. (2012) investigated the dynamic relationship between scientific innovation and economic growth in Beijing for 19912010 period with VAR model and reached a long-term equilibrium relationship between scientific innovation and economic growth.

Erdil et al. (2009) investigated the impact of Informatin and Communication Technologies (ICT) on economic growth for 131 underdeveloped and developing countries. Panel data analysis is carried out for 1995-2005 period and the results of the analysis showed that ICT has positive and significant effect on economic growth.

Sinha (2008) analyzed the relationship between patents and economic growth in Japan and South Korea using both individual country and panel data for 1963-2005 period. A cointegration and a two-way causality between the growth of real GDP and the growth of the number of patents is reached for Japan. And a cointegration is also found for South Korea. For panel data growth of real GDP Granger causes the growth of the number of patents.

\section{DATA AND METHODOLOGY}

In this study the relationship between high-technology exports, patent and economic growth have been investigated for 19902015 period in Turkey. All variables has been expressed in logarithmic form. The data have been provided from Organization for Economic Co-operation and Development (OECD). Stationarity of series have been investigated by Augmented Dickey-Fuller (ADF) test, the causality relationship between variables has been examined by VAR Granger Causality test. For long term relationship, Johansen Cointegration test has been carried out and lastly the long term causality has been investigated by VEC) Granger causality test. All analysis have been carried out by Eviews 10.0. GDP, HTEC, PTNT represent gross domestic product, high-technology exports and patent applications respectively.

Non-stationary time series can lead false regression issue, therefore the series should be stationary before establishing VAR Model. Dickey and Fuller (1979) designed three different models by including the lagged values of independent variables to the analysis. When the null hypothesis is rejected it is decided that the series do not contain unit root. By Granger causality test, the causality relationship between series are investigated by using equation (1) and (2). When the calculated statistic is bigger than the table value at $\alpha$ significance level and $(m ; n-2 m)$ degree of freedom, the null hypothesis is rejected. If a causality found from $X t$ to Yt variable, the coefficients of equation (1) become statistically significant (Granger, 1969).

$$
\begin{aligned}
& Y_{t}=\alpha_{0}+\sum_{i=1}^{p} \emptyset_{i} Y_{t-i}+\sum_{i=1}^{q} \delta_{i} X_{t-i}+\varepsilon_{t} \\
& X_{t}=\beta_{0}+\sum_{i=1}^{p} \pi_{i} X_{t-i}+\sum_{i=1}^{q} \lambda_{i} Y_{t-i}+\mu_{t}
\end{aligned}
$$


Long term relationship is investigated by Johansen cointegration test developed by Johansen (1991) since the series are equally integrated and is conduted by the help of equation (3).The number of cointegration vectors are shown by the matrix $\pi$ rank. When there is no cointegration the rank of $\pi$ equals to zero. If long term relationship exist between the series, to determine the direction of the long-term relationship VEC is use which was developed by Engle-Granger (1987).

$$
\Delta \mathrm{yt}=\sum_{i=1}^{k-1} \pi_{i} \Delta \mathrm{y}_{t-1}+\pi \mathrm{y}_{t-k}+\varepsilon_{t}
$$

\section{FINDINGS AND DISCUSSIONS}

It has been determined that series are non-stationary at level form and first differences of series are used which are stable by ADF. As presented in Table 1, the ADF test results showed that calculated t-statistic values are bigger than McKinnon critical values at first differences of series. The characteristic roots of the model are contained within the unit circle which also confirms the stability of the VAR model (Figure 1).

\section{Table 1: ADF Test}

\begin{tabular}{|c|c|c|c|c|}
\hline \multirow{2}{*}{ Variable } & \multicolumn{4}{|c|}{ Constant, Linear Trend } \\
\cline { 2 - 5 } & Level & \multicolumn{2}{c|}{ First Difference } \\
\cline { 2 - 5 } & t-statistics & $\begin{array}{c}\text { McKinnon } \\
\text { Critical Value } \\
\mathbf{( \% 5 )}\end{array}$ & t-statistics & $\begin{array}{c}\text { McKinnon } \\
\text { Critical Value } \\
\text { (\%5) }\end{array}$ \\
\hline GDP & -2.225696 & -3.603202 & -8.954988 & -3.622033 \\
\hline HTEC & -1.860968 & -3.603202 & -4.678110 & -3.690814 \\
\hline PTNT & -2.569282 & -3.658446 & -6.977945 & -3.632896 \\
\hline
\end{tabular}

Figure 1: Characteristic Roots

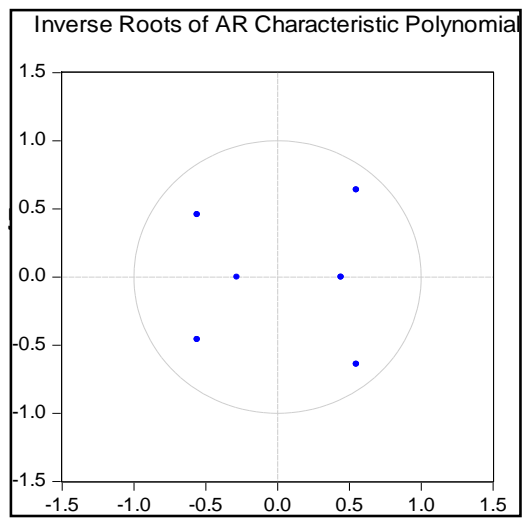

Before establishing VAR model for causality test, the appropriate lag length should be determined. In this study the appropriate lag length for VAR model has been selected as 2 at final predicting error (FPE), Akaike (AIC), Schwarz (SC) and Hannan-Quinn (HQ) values. According to VAR Granger Causality test, a causality relationship exists from high-technology exports to economic growth and also a causality relationship is found from patent to economic growth (Table 2). 
Table 2: VAR Granger Causality Test

\begin{tabular}{|c|c|c|}
\hline \multicolumn{3}{|c|}{ Dependent Variable: DGDP } \\
\hline Independent Variable & Chi-sq & Probability \\
\hline DHTEC & 9.454907 & 0.0088 \\
\hline DPTNT & 10.73066 & 0.0047 \\
\hline \multicolumn{3}{|c|}{ Dependent Variable: DHTEC } \\
\hline Independent Variable & Chi-sq & Probability \\
\hline DGDP & 3.378708 & 0.1846 \\
\hline DPTNT & 0.220599 & 0.8956 \\
\hline Independent Variable & Chi-sq & Probability \\
\hline DGDP & 0.136351 & 0.9341 \\
\hline DHTEC & 1.017140 & 0.6014 \\
\hline
\end{tabular}

Long term relationship has been investigated by Johansen Cointegration test. It has seen that the trace statistic is bigger than critical value and the null hyphotesis has been rejected. According to test results 2 cointegating vectors have been determined and the existance of long term relationship between variables has been accepted. Table 3 shows the number of cointegrating vectors.

Table 3: Johansen Cointegration Test

\begin{tabular}{|c|c|c|c|c|}
\hline $\begin{array}{c}\text { Hypothesized } \\
\text { No.of CE(s) }\end{array}$ & Eigenvalue & Trace Statistic & Critical Value (\%5) & Probability \\
\hline$r=0$ & 0.511149 & 28.45084 & 24.27596 & 0.0140 \\
\hline$r \leq 1$ & 0.427963 & 12.70551 & 12.32090 & 0.0431 \\
\hline$r \leq 2$ & 0.018793 & 0.417389 & 4.129906 & 0.5817 \\
\hline
\end{tabular}

To determine the causality relationship between variables in long term, VEC Granger Causality test has been carried out which is developed by Engle-Granger (1987) and causality relationships have been found from both high-technology exports and patent to economic growth (Table 4).

Table 4: VEC Granger Causality Test

\begin{tabular}{|c|c|c|}
\hline \multicolumn{3}{|c|}{ Dependent Variable: DGDP } \\
\hline Independent Variable & Chi-sq & Probability \\
\hline DHTEC & 7.979688 & 0.0185 \\
\hline DPTNT & 10.04952 & 0.0066 \\
\hline \multicolumn{3}{|c|}{ Dependent Variable: DHTEC } \\
\hline Independent Variable & Chi-sq & Probability \\
\hline DGDP & 0.249799 & 0.8826 \\
\hline DPTNT & 0.102074 & 0.9502 \\
\hline \multicolumn{3}{|c|}{ Dependent Variable: DPTNT } \\
\hline Independent Variable & Chi-sq & Probability \\
\hline
\end{tabular}




\begin{tabular}{|c|l|l|}
\hline DGDP & 1.081716 & 0.5822 \\
\hline DHTEC & 0.395359 & 0.8206 \\
\hline
\end{tabular}

\section{CONCLUSION}

The production and export of high-technology products accelerate growth due to the high added value of these products. Developing innovative approaches, intensification of R \& D activities and increases in patent applications are important for achieving economic growth and achieving competitive advantage. In this study, the causality and long term relationship between high-technology exports, patent and economic growth have been examined for Turkish economy for 1990-2015 period. According to study Granger causality test result causality relationships have been found from high-technology exports and patent to economic growth. Long term relationship between variables has been determined by Johansen Cointegration test and lastly by VEC Granger causality test, a causality relationship from high-technology exports to economic growh and also a one way causality relationship from patent to economic growth have been found. It is necessary to establish science and technology policies in Turkey to support the adoption of innovation-oriented strategy, the dissemination of patent applications and the production and export of high-technology products. By harmonized science and technology policies it will be possible to provide funds to the researchers and to realize investments required for advanced technology production.

\section{REFERENCES}

Aali Bujari, A.,Venegas Martínez, F. (2016). Technological Innovation and Economic Growth in Latin America. Mexican Journal of Economics and Finance, 11(2): 77-89.

Aghion, P.,Howitt, P. (1992). A Model of Growth Through Creative Destruction. Econometrica, 60(2): 323-351.

Algan N, Manga, M, Tekeoğlu, M. (2017). Teknolojik Gelişme Göstergeleri ile Ekonomik Büyüme Arasındaki Nedensellik ilişsisi: Türkiye Örneği. International Conference on Eurasian Economies 2017: 332-338.

Alper, A.E. (2017). Türkiye'de Patent, Ar-Ge Harcamaları, İhracat ve Ekonomik Büyüme Arasındaki İlişki: Bayer-Hanck Eş Bütünleşme Analizi. International Congress on Politic, Economic and Social Studies, 3: 17-26.

Arrow, K. J. (1962). The Economic Implications of Learning by Doing. The Review of Economic Studies, 29(3): 155-173.

Dickey, D., Fuller, W. A. (1979). Distribution of the Estimates for Autoregressive Time Series with a Unit Root. Journal of the American Statistical Association, 74, 427-431.

Engle, R.F., Granger C.W.J. (1987). Cointegration and Error Correction: Representation, Estimation, and Testing. Econometrica, 55: $251-276$.

Erdil, E., Turkcan, B , Yetkiner, I. H. (2009). Does information and communication technology sustain economic growth ? The underdeveloped and developing countries case. Science And Technology Polıcies Research Center TEKPOL Working Paper Series,09(03): 1-15.

Granger, C.W.J. (1969). Investigating Causal Relations By Econometric Models and Cross-Spectral Methods. Econometrica, 37(3), 424-438.

Grossman, G. M., Helpman, E. (1991a). Endogenous Product Cycles. The Economic Journal, 101:1214-1229.

Grossman, G. M., Helpman, E. (1991b) .Quality Ladders and Product Cycles. Quarterly Journal of Economics, 106: 557-586.

Işık, C. (2014) “Patent Harcamaları ve İktisadi Büyüme Arasındaki İlişki: Türkiye Örneği”, Sosyoekonomi, 1: 69-86.

Johansen, S. (1991). Estimation and Hypothesis Testing of Cointegration Vectors in Gaussian Vector Autoregressive Models. Econometrica, 59: 1551-1580.

Kabaklarlı, E., Duran, M.S., Telli Üçler, Y. (2018). High_Technology Exports and Economic Growth: Panel Data Analysis for selected OECD Cuntries. Forum Scientiae Oeconomia, 6(2): 47-60.

Kılavuz, E., Topçu Altay, B. (2012). Export and economic growth in the case of the manufacturing Industry: Panel data analysis of developing countries. International Journal of Economics and Financial Issues, 2(2): 201-215.

Konak, A. (2018). Yüksek Teknoloji İçeren Ürün İhracatının ihracat Hacmi ve Ekonomik Büyüme Üzerine Etkisi; Seçilmiş OECD Ülkeleri ve Türkiye Örneği. Yönetim, Ekonomi, Edebiyat, islami ve Politik Bilimler Dergisi, 3(2): 56-80. 
Lucas, R. E. (1988). On The Mechanics of Economic Development. Journal of Monetary Economics, (22): 3-42.

Romer, P.M. (1986). Increasing Returns And Long-Run Growth. The Journal of Political Economy, 94(5): 1002-1037.

Romer, P. M. (1990). Endogenous Technological Change. The Journal Of Political Economy, 98(5): 71-102.

Sinha, D. (2008). Patents, Innovations And Economic Growth In Japan and South Korea: Evidence From Individual Country and Panel Data. Applied Econometrics and International Development, 8(1): 1-23.

Song, Z. S., Nan, G. J. (2014). Empirical studies of the relationship between technological innovation and economic growth-Shanghai-based panel data analysis. BioTechnology: An Indian Journal, 10(9): 3758-3764.

Solow, R. M. (1956). A Contribution to the Theory of Economic Growth. The Quarterly Journal of Economics: 65-94.

Swan, T. W. (1956). Economic Growth and Capital Accumulation. Economic record, 32(2): 334-361.

Telatar, O.M, Değer, M.K., Doğanay M.A. (2016). Teknoloji Yoğunluklu Ürün İhracatının Ekonomik Büyümeye Etkisi: Türkiye Örneği (1996:Q1-2015:Q3). Atatürk Üniversitesi Iktisadi ve İari Bilimler Dergisi 30(4): 921-934.

TÜBіTAK (2004). Bilim ve Teknoloji Stratejileri-Vizyon 2023. www.vizyon2023.tubitak.gov.tr/genelbilgi/

Özçelik, Ö., Aslan, V., Özbek, R.í. (2018). Ar-Ge Harcamalarıyla Yüksek Teknoloji İhracatı Arasındaki İlişki: Seçili 10 OECD Ülkesi İçin Panel Veri Analizi. Kastamonu Üniversitesi Iktisadi ve Idari Bilimler Fakültesi Dergisi, 20(3): 57-66.

Özkan. G., Yılmaz. H. (2017). Ar-ge harcamalarının yüksek teknoloji ürün ihracatı ve kişi başı gelir üzerindeki etkileri: 12 AB ülkesi ve Türkiye için uygulama (1996-2015). Bilgi Ekonomisi ve Yönetimi Dergisi, 12(1): 1-12.

Ustabaş, A., Ersin, Ö. (2016). The Effects of R\&D and High Technology Exports on Economic Growth: A Comparative Cointegration Analysis for Turkey and South Korea. International Conference On Eurasian Economies: 44-55.

Weng, L., Song, W.,Sheng, S. (2012). Empirical Research on Scientific and Technical Innovation and Economic Growth in Shanghai. American Journal of Operations Research, 2: 82-90.

Zhang, L., Song, W., He, J. (2012). Empirical Research on the Relationship Between Scientific Innovation and Economic Growth in Beijing. Technology \& Investment, 3(3): 168-173.

Yıldız, Ü. (2017). Brics Ülkeleri ve Türkiye' de İleri teknoloji İhracatı ve Ekonomik Büyüme İlişkisinin Panel Veri Analizi. Dumlupınar Üniversitesi Sosyal Bilimler Dergisi, 53: 26-34. 